\title{
Primary Non-Hodgkin Lymphoma of Bone
}

National Cancer Institute

\section{Source}

National Cancer Institute. Primary Non-Hodgkin Lymphoma of Bone. NCI Thesaurus.

Code C121930.

A non-Hodgkin lymphoma that arises from the bone, without lymph node or other extranodal involvement. The femur, spine, and pelvic bones are the most frequently affected areas. The majority of cases are diffuse large B-cell lymphomas. Most patients present with pain in the affected area. Systemic symptoms are rare. 